\title{
The Ability of Indonesian Language Education Students in Designing Lesson Plan through Teaching Practice in School
}

\author{
Martono $^{1}$, Jagad Aditya Dewantara ${ }^{2, *}$, Soeharto ${ }^{3}$ \\ ${ }^{1}$ Department of Language Education, Universitas Tanjungpura, Indonesia \\ ${ }^{2}$ Department of Civic Education, Universitas Tanjungpura, Indonesia \\ ${ }^{3}$ Faculty of Humanity and Social Sciences, Doctoral School of Education, University of Szeged, Hungary
}

Received July 27, 2020; Revised August 31, 2020; Accepted September 29, 2020

\section{Cite This Paper in the following Citation Styles}

(a): [1] Martono, Jagad Aditya Dewantara, Soeharto , "The Ability of Indonesian Language Education Students in Designing Lesson Plan through Teaching Practice in School," Universal Journal of Educational Research, Vol. 8, No. 11, pp. 5489 - 5497, 2020. DOI: 10.13189/ujer.2020.081152.

(b): Martono, Jagad Aditya Dewantara, Soeharto (2020). The Ability of Indonesian Language Education Students in Designing Lesson Plan through Teaching Practice in School. Universal Journal of Educational Research, 8(11), 5489 5497. DOI: 10.13189/ujer.2020.081152.

Copyright $@ 2020$ by authors, all rights reserved. Authors agree that this article remains permanently open access under the terms of the Creative Commons Attribution License 4.0 International License

\begin{abstract}
Indonesian education study program students are prepared to become professional teachers. Students are given one course, including learning planning, as a condition for implementing teaching practice in school. To find out the success of practical teaching activities, researchers researched to determine the ability of Indonesian education study program students in designing learning plans. This study aims to assess lesson plans made by Indonesian education study program students and provide development instruments to evaluate teacher performance. This research method is a quantitative study using a device in the form of an assessment scale to assess lesson plans made by prospective teachers in Indonesian education study programs. Students are investigated according to their ability to design lesson plans through teaching practice at senior or junior high school according to placement from university. The statistics used in this study are descriptive in the form of percentages and categories of students' ability to develop learning plans by aspects of the instrument. Participants in this study consisted of 131 undergraduate students in Indonesian education. The results of student data analysis have been seen well from the following five aspects. (1) Formulation of learning objectives, (2) designing selection and organizing, (3) choosing learning resources/learning media, (4) learning strategies and methods, and (5) evaluating
\end{abstract}

learning outcomes. An instrument to assess teacher performance was created and used in determining undergraduate students in Indonesian education study programs. The assessment instruments classify lesson plans into several aspects to be evaluated. With this assessment instrument, instructors will quickly assess students' lesson plans, and teachers can improve their ability to design lesson plans.

Keywords Language Education, Lesson Plans, Designing of Lesson Plan

\section{Introduction}

Education plays an important role in life today. Without good education, people will not be able to compete in the face of this highly competitive globalization [1], [2]. Therefore, the teachers are important elements in education that are required for their abilities in all fields [3]. There are a lot of controversies about the approach to prepare new teachers, with what needs to be prepared, one of which is the ability to design lesson plan [4]. Indonesian language education students are prepared to become professional teachers. To be a professional teacher takes a serious effort. 
The readiness of the institution becomes the key for producing qualified graduates. The institution must prepare qualified human resources (lecturers and staff), complete and good infrastructure, good academic atmosphere on campus. Teacher involvement with pedagogical reforms and in suggesting a framework for designing PE programs for specific need are also very important [5]. The circumstances where teachers work together at schools determine the process of teaching and learning process. For example, the availability of modelling on the use of technology and teaching approaches helps teachers in the process of teaching and learning [6].

During college, they are given courses that support to prepare them to become professional teachers. In the curriculum of the Indonesian Language Education, course is presented subjects related to general courses, faculty courses, and courses of study. The determination of the course follows the prescribed guidelines of the ministry and follows the Indonesian language education association.

Students who will take micro teaching courses are required to pass all the required subjects. One of the subjects that is a prerequisite for taking a micro teaching course is the Indonesian language learning planning course. Passing this course is a must for the students. Those who will be micro-teaching (Practice Teaching 1) and Practice Teaching 2 must create lesson plans. Therefore, students should be able to design their teaching and learning plans. To help the students of the Indonesian Language Education program become professional teacher candidates, they are obliged to learn to be teachers in the faculty with small groups. The course is micro teaching. Students who have passed the microteaching are allowed to take PPL 2 courses. PPL 2 course is held in school for six months. They practice teaching in schools with guidance from lecturers and tutor teachers. It is expected that after taking the PPL 2 course they are skilled at drawing up the lesson plan (RPP) and at applying the lesson plan in front of the class.

For a professional teacher, planning in accordance with the duties and responsibilities of his profession is a step that should not be abandoned [7]. According to Kirschling (1992), there are two reasons for the necessity of planning: First, human nature has the ability and choice to be creative in accordance with its views [8]. A professional can determine the timing and the manner of actions; second, every human living in a group is interconnected with each other. Thus, coordination is required in carrying out various activities. Thus, a job will succeed when all those involved can work according to their respective roles. Two things are then needed in planning to do something. Planning for teaching and learning become very important in teaching and learning process [9].

But in fact, there are still students who have difficulty in designing learning plans. Students experience difficulties when designing learning plans that use innovative learning models. They also find difficulties in choosing the right innovative learning model to teach certain material. In addition, students have difficulty doing the learning steps based on the model chosen.

\subsection{Research Focus and Scope}

Students of Indonesian language study program are required to take practice teaching 2 . They do practice teaching 2 for six months in school. After implementing practice teaching 2 students are required to make a report during practice teaching 2 at school. The report was one of them the RPP they used to teach during practice teaching 2 at school. The process of making practice teaching 2 at school gets guidance from teachers and guidance counsellors.

Indonesian language education students are still having difficulties in designing lesson plans. This happens because of difficulties in the selection and organizing of teaching materials, selection of learning resources/media, integrating the strategies and models of learning that they choose, and the assessment of learning outcomes. The researcher found this problem in student's thesis. Research objectives are to know (1) The ability of Indonesian Language Education students to design the formulation of learning objectives in the learning program plan, (2) The ability of Indonesian Language Education students to design the selection and organizing of teaching materials in the learning program plan, (3) The ability of Indonesian Language Education students to design the selection of learning resources / learning media in the learning program plan, (4) The ability of Indonesian Language Education students to design strategies and learning methods in the learning program plan, (5) The ability of Indonesian Language Education students to design assessment of learning outcomes in the program plan of learning.

This research is to focus the research on the lesson plans made by the students of the Indonesian Education Study Program. Planning learning which includes, the formulation of learning objectives, selection and organizing teaching materials, selection of learning resources / learning media, strategies and learning methods, and assessment of learning outcomes. The lesson plan of the Learning Program was obtained when the student made the report on the implementation of practice teaching in the school.

\section{Materials and Methods}

The method used in this research plan is descriptive method. A descriptive method is used to give a true picture of the ability of Indonesian language study program students to design their lesson plans. This method can be interpreted as a problem-solving procedure that is investigated by describing or describing the state of the current research subject based on apparent facts. 


\section{a. Forms of Research}

The design of this research is quantitative. This form of research is to analyze the ability of Indonesian language education students to design the Learning Program Plan. Researchers choose quantitative form because it is considered appropriate for the problem to be studied, that is analyzing the ability of Indonesian language education student to design lesson plan from the aspect of the formulation of learning objectives, the selection, and organizing of teaching materials, the selection of learning resources/media, the determination of learning strategy and method. However, there are some limitations of quantitative methods such as the interpretation according to group central statistics and no personal interpretation from qualitative data.

\section{b. Population and sample}

Population in this research is student of study program of Indonesian language taking the subject of PPL 2. The number of students who take this subject is 131 people. They make reports in the form of Lesson Plans (RPP). All students become the participants of the study (sample subject) from all the population. All the participants' lesson plans are taken to for this study [10].

\section{c. Data Collection Techniques and Tools}

This study is a documentary study. The data of this research are RPP which have been made by the Students of Indonesian Language Program as a report during PPL 2. The tool used to assess the RPP is IPKG format 1.

\section{d. Data analysis technique}

The focus of this research is related to the design of learning planning program including designing from the aspect of the formulation of learning objectives, the selection and organizing of teaching materials, the selection of learning resources/media, the determination of learning strategies and methods, and the assessment of learning outcomes. Each aspect is assessed by criteria 1, 2, 3,4 .

$$
\begin{aligned}
& \text { Information: } \\
& \begin{array}{l}
1=\text { Poor } \\
2=\text { Fair } \\
3=\text { good } \\
4=\text { very good }
\end{array}
\end{aligned}
$$

Final value $=\frac{\text { Acquisition Score }}{\text { Maximum Score }} \times$ ideal score (100)

Criteria for determining the value of each aspect of RPP.

$$
\begin{aligned}
\mathbf{N} & =\frac{\text { Number of aspect values }}{\text { Number of students }} \\
3.01-4.00 & =\text { very good } \\
2.51-3.00 & =\text { good } \\
2.01-2.50 & =\text { fair } \\
1.00-2.00 & =\text { poor }
\end{aligned}
$$

\section{Result and Discussion}

Figure 1 in this study shows the percentage of teacher performance in designing lesson plan based on the aspects being assessed (IPKG1). Figure 2 gives us information about the value of every aspect according to the rating scale. The data in instrument have 1 scale (series1) and 3 scales (series 2).

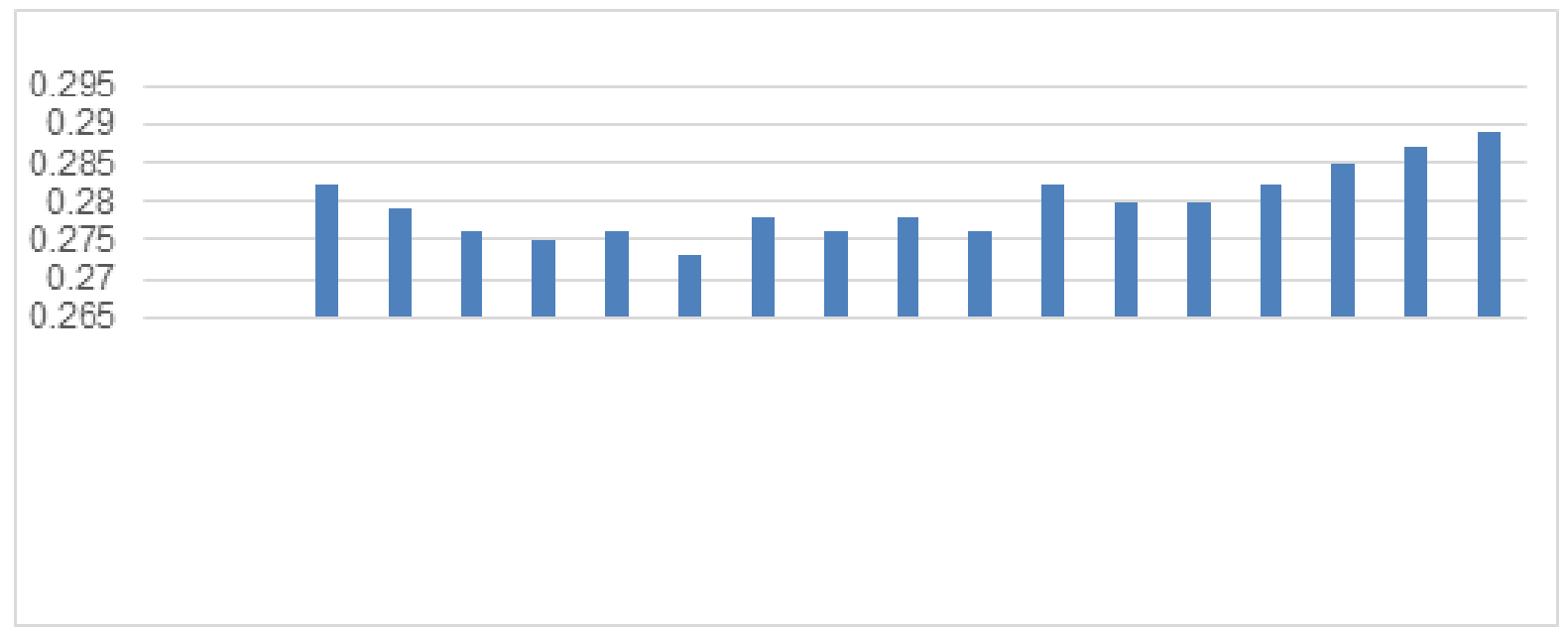

Figure 1. Percentages of teacher performance assessment instrument in designing lesson plan (IPKG1) according to aspects 


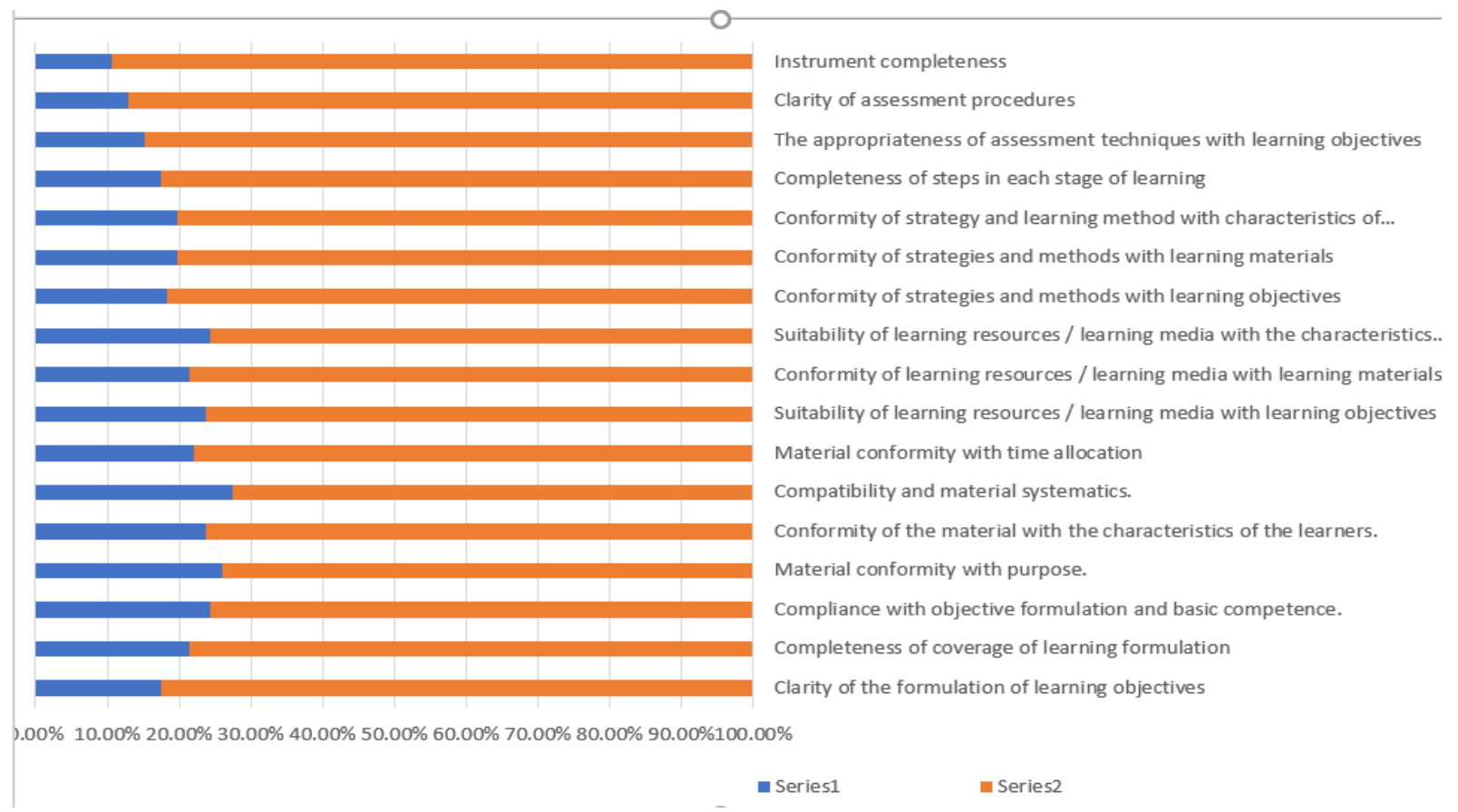

Figure 2. Proportions of Lesson plan according to raters

Based on the results of the analysis of this research instrument in Figure 1 and Figure 2 , it can be described the ability of Indonesian language study program students to design the plan of Indonesian language learning program as follows.

a. The ability of Indonesian language study program students to design the learning program plan seen from the formulation of learning objectives there are three aspects. (1) Clarity of the formulation of learning objectives. This aspect value is 2.82 (good). Students who received a score of 2 (fair) as many as 23 people (17.55\%). Students who scored 3 (good) as many as 108 people (82.44\%). (2) Completeness of coverage of learning formulation. The value of this aspect is 2.79 (good). Students who received a score of 2 (fair) as many as 28 people (21.37\%). Students who received a score of 3 (good) as many as 103 people (78.62\%). (3) Compliance with objective formulation and basic competence. The value of this aspect is 2.76 (good). Students who received a score of 2 (fair) as many as 32 people (24.42\%). Students who scored 3 (good) were 99 (75,57\%).

b. The ability of Indonesian language education study program students to design the learning program plan seen from the designing of the selection and organizing of teaching materials there are four aspects. (1) Material conformity with purpose. This aspect value is 2.75 (good). Students who received a score of 2 (fair) are 34 (25.95\%). Students who are scored 3 (good) are (74.04\%). (2) Conformity of the material with the characteristics of the learners. The value of this aspect is 2.76 (good). Students who received a score of 2 (fair) as many as 31 (23.66\%). Students who received 3 (good) score of 100 (76.33\%). (3) Compatibility and material systematics. The value of this aspect is 2.73 (good). Students who received a score of 2 (fair) are 36 (27.48\%). Students who scored 3 (good) were 95 (72,51\%). (4) Material conformity with time allocation. The value of this aspect is 2.78 (good). Students who received a score of 2 (fair) are 29 (22.13\%). Students who received 3 (good) score of 102 (77,86\%).

c. The ability of Indonesian language education program students to design the learning program plan seen from the aspect of selection of learning resources/learning media there are three aspects. (1) Suitability of learning resources / learning media with learning objectives. The value of this aspect is 2.76 (good). Students who received a score of 2 (fair) as many as 31 (23.66\%). Students who received 3 (good) score of 100 (76.33\%). (2) Conformity of learning resources / learning media with learning materials. The value of this aspect is 2.78 (good). Students who received a score of 2 (fair) are 28 (21.37\%). Students who received a score of 3 (good) as much as 103 (78.62\%). (3) Suitability of learning resources / learning media with the characteristics of learners. The value of this aspect is 2.76 (good). Students who received a score of 2 (fair) are 32 (24.42\%). Students who received 3 (good) score of 99 (75,57\%).

d. The ability of Indonesian language study program students to design the learning program plan from the aspects of strategy and learning method are four aspects. (1) Conformity of strategies and methods with learning objectives. This aspect value is 2.82 (good). Students who received a score of 2 (fair) as 
many as $24(18.32 \%)$. Students who scored 3 (good) are 107 (81.67\%). (2) Conformity of strategies and methods with learning materials. This aspect value is 2.80 (good). Students who received a score of 2 (fair) are $26(19.84 \%)$. Students who received 3 (good) score of 105 (80.15\%). (3) Conformity of strategy and learning method with characteristics of learners. This aspect value is 2.80 (good). Students who received a score of 2 (fair) are 26 (19.84\%). Students who received 3 (good) score of 105 (80.15\%). (4) Completeness of steps in each stage of learning. This aspect value is 2.82 (good). Students who received a score of 2 (fair) as many as $23(17.55 \%)$. Students who scored 3 (good) are 108 (82.44\%).

e. The ability of Indonesian language study program students to design the learning program plan seen from the aspect of the assessment of learning outcomes there are three aspects. (1) The appropriateness of assessment techniques with learning objectives. This aspect value is 2.85 (good). Students who get 2 (fair) are 20 (15,26\%). Students who scored 3 (good) are 111 (84.73\%). (2) Clarity of assessment procedures. The value of this aspect is 2.87 (good). Students who received a score of 2 (fair) as much as $17(12.97 \%)$. Students who received a score of 3 (good) are 114 (87.02\%). (3) Instrument completeness. This aspect value is 2.89 (good). Students who received a score of 2 (fair) as many as 14 (10.68\%). Students who scored 3 (good) of 117 (89.31\%).

\subsection{The Nature of Learning Planning}

Learning is a process that aims. The process is directed to achieve a goal. Teachers who only carry out the learning process by using lectures, of course, the teacher's speech is directed to achieve the goal; as well as teachers who do the learning process by analyzing the case, then the process of case analysis is a process that aims. To realize the goal then, the teacher must make learning planning [11]. The teacher must be involved more with the program material when they feel it is practical, relevant and applicable [12]. Making lesson plan has been an essential part in teaching and learning process. Lesson plan in STEM education has been developed, and used in lesson study [13], [14].

Martono (2017) describes learning planning as "An intellectual process to help teachers systematically analyze learner needs and construct structure possibilities to responsively address those needs" [15]. Thus, a learning plan is directed to analyze the students' needs in learning and then attempts to assist in answering those needs. A learning plan helps teacher to develop learning process and an effective path to help them in enhancing teaching skill, confidence, and knowledge in teaching and learning process [16], [17].

\subsection{Criteria for Preparation of Learning Planning}

Learning planning is made not only as a complementary administration but is structured as an integral part of the professional work process, so that it serves as a guide in the implementation of learning. Thus, the preparation of the lesson planning is a necessity because it is driven by the need for the implementation of targeted learning in accordance with the objectives and targets to be achieved. Criteria for preparing lesson plan before used in classroom are essential because lesson plan can help implication for student teacher preparation and teaching effectiveness in classroom [18], [19].

Criteria for the Preparation of Learning Planning as follows.

\section{Significance}

Significance in this context can be interpreted as meaningfulness. The value of significance means, that the planning of advocacy should be meaningful for the learning process to be effective and efficient. Therefore, learning planning is arranged as part of the learning process in accordance with the needs of students. Lesson planning is not placed as a complement. Thus, in the teaching and learning process, teachers should be guided by the planning that has been prepared.

\section{Relevant}

Relevant means appropriate. The value of relevance in planning is that the planning we arrange has a value of conformity both internal and external. Internal conformity is that learning planning must be in accordance with the applicable curriculum. Why is that? The main source of lesson planning is the curriculum itself. The curriculum that determines the goals to be achieved, determines the material or lesson materials that students should learn and so on. External conformity implies, that the planned learning plan must be in accordance with the needs of the students. Why is that? Learning planning is essentially designed to assist students in achieving learning objectives. Therefore, matters relating to students such as student interests and talents, student learning styles, students' learning abilities and so on, should be considered first from the point of external conformity.

\section{Certainty}

To achieve the learning objectives, many alternatives can be used. However, in so many alternatives, teachers should determine which alternatives are appropriate and can be implemented. The value of certainty means that in the lesson planning that serves as a guide in the implementation of the learning process, no longer contains alternatives that can be selected but contains the definite steps that can be done systematically. With that certainty, we will avoid problems that may arise unexpectedly.

\section{Adaptability}

Planned learning planning should be flexible. For 
example, this learning planning can be implemented if it has certain conditions. If the condition is not met, then the lesson plan cannot be used. Such learning planning is rigid planning, as it requires special requirements. Better learning planning is structured to be implemented in various circumstances and conditions. Thus, the plan can be used by everyone who will use it.

\section{Simplicity}

Lesson planning should be simple and easy to translate and easy to implement. Complex and difficult planning to implement will not serve as a guide for teachers in learning management. Master has difficulty using it.

\section{Predictive}

Good learning planning must have strong predictive power, meaning planning can describe "what will happen, if ...". This prediction is very important to anticipate the various possibilities that will occur, thus will be easy for teachers to anticipate it.

\subsection{Steps for Preparation of Learning Planning}

To produce a good learning plan, there are several steps that must be followed. [20], [21]. Learning plan must pay attention to the steps when compiling it. Step-by-step in the preparation of lesson planning as follows.

\section{Formulate a Special Purpose}

Bas \& Beyhab (2017) said that the goals in learning procees in the lesson plan determine the direction of learning and the material to be achieved in the classroom. In designing learning, the teacher's first task is to formulate specific learning objectives and their subject matter [22]. Why should teachers design a specific plan? Because the general purpose is formulated by the curriculum developers. Teacher's job is to interpret the general purpose of learning to be a specific goal. The specific objectives were formulated as indicators of learning outcomes. The function of specific instructional formulas is as a technique for achieving general learning objectives. Thus, the achievement of specific objectives in the learning process is an indicator of achievement of general goals.

Formulation of learning objectives must include 3 important aspects. According to Bloom Taxonomy, the three aspects are cognitive domain, affective domain, and psychomotor domain.

\section{a. Cognitive domain}

Cognitive domains are learning objectives that are related to the development of the intellectual aspects of students through the mastery of knowledge and information. Mastery of knowledge and information such as mastery of data and facts, concepts, generalizations, and principles is a subject matter that will help even be important to the learning process at a higher stage. Cognitive domains play an important role in the direction of developing the lesson plan because it will determine what methods and instruments will be used to carry out learning practices so that cognitive aspects can be achieved [23], [24].

\section{b. Attitude and appreciation}

Affective domain (attitude) is a domain that is related to the acceptance and appreciation of a person to a thing. Affective domains come into contact with psychological aspects that are difficult to define in measurable (specific) behavioral forms. This is because the attitude and the appreciation aspects are associated with the mental development that exists in a person. Thus, the emerging aspects of behavior that a person show do not necessarily describe a person's attitude.

\section{c. Skills and appearance}

Domain skill is a domain that represents skills or skills (skills) a person can be seen from the performance or performance. Skill is a special learning objective that is related to motor skills (psychomotor domain). Skills can be physical skills and nonphysical skills. Physical skills are the skills of someone to do something by using muscles (playing drama, reading poetry). Implicit from Bloom's opinion above is that the success in learning will be achieved by most students if the learning program is carefully designed and all the factors related to individual student characteristics are considered carefully [7]. Teacher preparation for schools in designing lesson plan that serve children and the community must consider the context of the policy on the material presented in order to achieve the expected performance [25], [26].

\section{Learning Experience}

The second step in planning the learner is to choose the learning experience that students should do according to the learning objectives. Learning is not merely recording and memorizing, but experienced processors. Students should be actively encouraged to perform certain activities. Students are encouraged to seek and find out for themselves the facts, for example through interviews, observations, and so forth. Learning Experience is useful to train students to be accustomed to accepting various learning methods and models contained in the lesson plan. By having learning experience, students will understand the material that will be taught by the teacher in learning [27], [28].

The learning process can also be done by simulation or dramatization. The goal to be achieved is not just to remember but to live a certain role, which expects the students' mental and emotional development. We give students the opportunity to tell a picture or a picture. Allow students to interpret, criticize, and so on. Through pictures or photographs, we can train the students' ability to develop the imaginative ability that can stimulate the mental development and intelligence of the students. The development of the learning process can be carried out along with technological advances such as disclosing the media of animation or demonstration using a computer. 
The activity related to the integration of technology can be poured into the lesson plan to improve the quality of learning [29], [30].

\section{Teaching and Learning Activities}

Teaching and learning are important processes related to knowledge, skills, behavior, achievement of learning outcomes, etc. Teaching is the process of conveying knowledge to students to do or get something. learning is the acquisition obtained from the prose of teaching and learning [31], [32]. The third step in developing learning planning with system approach is to determine teaching and learning activities. Determining teaching and learning activities can be designed through a group approach or an individual approach. The group approach is a learning that is designed using a classical approach, ie each student learns in groups either in large groups or small groups. Individual learning is that students learn independently through learning materials so that students can learn according to their own pace and ability. According to Harmin \& Toth (2012) determines learning activities aimed at raising the best ability of students who are often accompanied by positive skills not yet known by the students themselves [33].

The three types of learning objectives such as cognitive, affective and psychomotor objectives, can basically use the approach of classical learning, learning through group or individual learning, depending on the specific objectives to be achieved. Of course, the learning approach taken will have consequences on the learning tasks that students must do.

\section{People Involved}

Planning learning with a system approach is also responsible for determining the person who helps in the learning process. The people involved in the learning process, especially those who serve as learning resources include instructors or teachers, as well as professionals.

The role of teachers in the learning process is as a manager of learning. In the implementation of these roles such as teachers function as a transmitter of information. In order for teachers to perform their functions and duties properly, the teacher must have the ability to speak and communicate, using various media such as OHP, LCD, whiteboard, and so forth. These capabilities are indispensable in acting as a transmitter of information.

Another role as a teacher is to organize the learning environment to provide an adequate learning experience for each student. The capability of the teacher for that describes the professional level and skill of the teacher. Teachers are required to be able to design and organize the environment so that students can learn passionately in accordance with their own learning styles.

\section{Materials and Tools}

Selection of materials and tools is also part of the learning planning system. Materials related to the material given to the students. Learning tools or media is a tool used by teachers to help deliver the material [34]. The determination of materials and tools may take the following matters into account:

1) The diversity of students' intellectual abilities.

2) The number and variety of specific learning goals that students must achieve.

3) Types of media produced and used specifically.

4) A variety of alternative learning experiences to achieve learning objectives.

5) Materials and tools that can be utilized.

6) Physical facilities available.

\section{Physical Facilities}

Physical facilities are factors that will affect the success of the learning process. Physical facilities include classrooms, media centers, laboratories, or rooms for large classes (sort of hall). Teachers and students will work together, using lesson materials, making use of tools, discussing, and so forth. All of that can only be used through careful planning process through professional arrangement including financial support as needed.

\section{Evaluation and Development Planning}

Evaluation procedure is an important factor in a learning planning system. Through the evaluation, we can see the success of learning management and the success of students achieving learning objectives. Based on the evaluation of all elements are available completely, then we can determine the next stage. Evaluation of student learning outcomes will provide information on:

1) Completeness of learning objectives.

2) Weaknesses in learning planning, namely the content of lessons, learning procedures, and also the lesson materials used.

3) Error diagnosing students about readiness following the learning experience.

4) The weaknesses of the instrument used to measure the ability of students to achieve learning objectives.

\section{Conclusions and Recommendations}

Based on the results of data analysis, it can be concluded the ability of undergraduate student in designing lesson plan is good, which can be grouped into several aspects: (a) The ability of Indonesian language education program students to design the learning program plan seen from the formulation of learning objectives there are three aspects. (1) the clarity of the formulation of the learning objectives got a value of 2.82 (good). (2) the completeness of the scope of the learning formulation received a score of 2.79 (good) (3) the suitability of the objective formulation and the basic competence received a score of 2.76 (good). (b) The ability of Indonesian language education study 
program students to design the learning program plan seen from the designing of the selection and organizing of teaching materials there are four aspects. (1) the suitability of the material with the objective with a value of 2.75 (good). (2) the suitability of the material with the characteristics of the learner got a score of 2.76 (good). (3) conformity and material systematics. The value of this aspect is 2.73 (good). (4) material conformity with time allocation. The value of this aspect is 2.78 (good). (c) The ability of Indonesian language education program students to design the learning program plan seen from the aspect of selection of learning resources/learning media there are three aspects. (1) the suitability of learning resources / learning media with learning objectives. The value of this aspect is 2.76 (good). (2) suitability of learning resources / learning media with learning materials. The value of this aspect is 2.78 (good). (3) suitability of learning resources / learning media with the characteristics of learners. The value of this aspect is 2.76 (good). (d) The ability of Indonesian language study program students to design the learning program plan from the aspects of strategy and learning method are four aspects. (1) the suitability of strategies and methods with learning objectives. This aspect value is 2.82 (good). (2) conformity of strategies and methods with learning materials. This aspect value is 2.80 (good). (3) the suitability of the strategy and the learning method with the characteristics of the learners. This aspect value is 2.80 (good). (4) completeness of the steps in each of the learning stages. This aspect value is 2.82 (good). (e) The ability of Indonesian language education program students to design the learning program plan seen from the aspect of the assessment of learning outcomes there are three aspects. (1) the appropriateness of assessment techniques with learning objectives. This aspect value is 2.85 (good). (2) clarity of assessment procedures. The value of this aspect is 2.87 (good). (3) instrument completeness. The value of this aspect is 2.89 (good).

There are some recommendations according to the result of this study. First, the students should be taught courses of learning planning. The focus of the material review is prioritized on the planning of the planning program. Before being given the assignment, students should make a visit to school so they know the condition of learning materials at school. Lastly when preparing the report of planning the planning program, the students should be required to hold consultations with teachers and supervisor lecturers, student coaching will not be serious about making a program plan for learning.

\section{REFERENCES}

[1] W. H. Prasetiyo et al., "Caring for the environment in an inclusive school: The Adiwiyata Green School program in
Indonesia,” Issues Educ. Res., vol. 30, no. 3, p. 2020, 2020.

[2] O. T. Hidayat, A. Muhibbin, W. H. Prasetiyo, Y. B. Setyadi, and J. A. Dewantara, "Global Citizen Preparation: Enhancing Early Childhood Education through Indonesian Local Wisdom,” vol. 8, no. 10, pp. 4545-4554, 2020, doi: 10.13189/ujer.2020.081023.

[3] W. Maba, I. B. K. Perdata, and I. N. Astawa, "Constructing assessment instrument models for teacher's performance, welfare and education quality,” Int. J. Soc. Sci. Humanit., vol. 1, no. 3, pp. 88-96, 2017.

[4] D. L. S. Larssen et al., "A literature review of lesson study in initial teacher education,” Int. J. Lesson Learn. Stud., 2018.

[5] T.-H. Choi and A. D. Walker, "A heuristic model for tailoring teacher development to educational reforms: Focusing on ambiguity and conflict generation," Teach. Teach. Educ., vol. 74, pp. 72-84, 2018.

[6] H. Öz, "Assessing pre-service English as a foreign language teachers' technological pedagogical content knowledge," Int. Educ. Stud., vol. 8, no. 5, 2015.

[7] G. R. Morrison, S. J. Ross, J. R. Morrison, and H. K. Kalman, Designing effective instruction. John Wiley \& Sons, 2019.

[8] J. M. Kirschling, Counseling the Bereaved. Pergamon Press, 1992.

[9] M. Martono, "Lesson Planning The Key to Success of The Teachers Teaching in the Classroom,” 2016.

[10] D. R. Sugiyono, "Statistika untuk Penelitian [Statistic for Research],” Alf. Bandung (2012.)(in Bhs. Indones., 2015.

[11] P. Eggen and D. Kauchak, "Learning Strategies and Models Teaching Content and Thinking Skills," Jakarta Indeks, 2012.

[12] N. Lander, N. Eather, P. J. Morgan, J. Salmon, and L. M. Barnett, "Characteristics of teacher training in school-based physical education interventions to improve fundamental movement skills and/or physical activity: A systematic review,” Sport. Med., vol. 47, no. 1, pp. 135-161, 2017.

[13] S. Ceylan and Z. Ozdilek, "Improving a sample lesson plan for secondary science courses within the STEM education," Procedia-Social Behav. Sci., vol. 177, pp. 223-228, 2015.

[14] R. Bjuland and R. Mosvold, "Lesson study in teacher education: Learning from a challenging case," Teach. Teach. Educ., vol. 52, pp. 83-90, 2015.

[15] M. Martono, Indonesian Language Learning Planning. Pontianak: STAIN Press, 2017.

[16] W. Cajkler and P. Wood, “Adapting 'lesson study'to investigate classroom pedagogy in initial teacher education: what student-teachers think," Cambridge J. Educ., vol. 46, no. 1, pp. 1-18, 2016.

[17] A. Ramli, A. Alberth, and M. Yazid, “An Analysis of Rural And Urban Areas Senior High School English Teachers' Ability In Developing Lesson Plan And Sylabus At Kolaka District,” J. Lang. Educ. Educ. Technol., vol. 3, no. 1, 2018.

[18] J. S. Lane and M. D. Talbert, "Examining lesson plan use among instrumental music education majors during practice 
teaching,” J. Music Teach. Educ., vol. 24, no. 3, pp. 83-96, 2015.

[19] D. J. Musselwhite and B. C. Wesolowski, "Evaluating the psychometric qualities of a rating scale to assess pre-service teachers' lesson plan development in the context of a secondary-level music performance classroom," J. Res. Music Educ., vol. 66, no. 3, pp. 338-358, 2018.

[20] J.-E. Lee, W. Lim, and H.-J. Kim, “Lesson Planning: How Do Pre-service Teachers Benefit from Examining Lesson Plans with Mathematics Teaching Practices as an Analytical Lens?,” Educ. Prim. Sch. Math., vol. 19, no. 3, pp. 211-222, 2016.

[21] J. E. Kemp and M. Asril, Proses perancangan pengajaran. Penerbit ITB, 1994.

[22] G. Baş and Ö. Beyhab, "Effects of multiple intelligences supported project-based learning on students' achievement levels and attitudes towards English lesson,” Int. Electron. J. Elem. Educ., vol. 2, no. 3, pp. 365-386, 2017.

[23] E. W. Chizhik and A. W. Chizhik, "Using activity theory to examine how teachers' lesson plans meet students' learning needs,” Teach. Educ., vol. 53, no. 1, pp. 67-85, 2018.

[24] W. G. Bowen and M. S. McPherson, Lesson plan: An agenda for change in American higher education, vol. 90. Princeton University Press, 2017.

[25] R. A. Kaufman and F. W. English, Needs assessment: Concept and application. Educational Technology, 1979.

[26] C. Sleeter, C. Montecinos, and F. Jiménez, “Preparing teachers for social justice in the context of education policies that deepen class segregation in schools: The case of Chile," in Teacher education for high poverty schools,
Springer, 2016, pp. 171-191.

[27] D. Alt, “Science teachers' conceptions of teaching and learning, ICT efficacy, ICT professional development and ICT practices enacted in their classrooms," Teach. Teach. Educ., vol. 73, pp. 141-150, 2018.

[28] J. A. Schmidt, J. M. Rosenberg, and P. N. Beymer, “A person - in - context approach to student engagement in science: Examining learning activities and choice,” J. Res. Sci. Teach., vol. 55, no. 1, pp. 19-43, 2018.

[29] D. Uerz, M. Volman, and M. Kral, “Teacher educators' competences in fostering student teachers' proficiency in teaching and learning with technology: An overview of relevant research literature,” Teach. Teach. Educ., vol. 70, pp. 12-23, 2018.

[30] C. H.-H. Tsay, A. Kofinas, and J. Luo, "Enhancing student learning experience with technology-mediated gamification: An empirical study," Comput. Educ., vol. 121, pp. 1-17, 2018.

[31] K. Ali, D. Zahra, E. McColl, V. Salih, and C. Tredwin, "Impact of early clinical exposure on the learning experience of undergraduate dental students,” Eur. J. Dent. Educ., vol. 22, no. 1, pp. e75-e80, 2018.

[32] A. et. al. Malik, Pedoman Akreditasi Sekolah/Madrasah, 1st ed. Jakarta. Jakarta: Badan Akreditasi Nasional Sekolah/Madrasah, 2019.

[33] M. Hamrin and M. Toth, Pembelajaran Aktif yang Menginspirasi: Buku Pegangan Lengkap untuk Masa Kini. Jakarta: PT. Indeks, 2012.

[34] S. Arief, "Media pendidikan, pengertian, pengembangan, dan pemanfaatannya,” Jakarta PT. Rajagrafindo Persada, 2009. 